\title{
Faces da cultura visual e da aprendizagem: um estudo das máscaras da Festa de São Tiago de Mazagão Velho
}

\section{Ronne F. Carvalho \\ DIAS}

\section{Resumo}

Nesta pesquisa pretendo analisar relações simbólicas e identitárias de processos de aprendizagem da feitura e utilização de máscaras da Festa de São Tiago de Mazagão Velho, estado do Amapá. A festa acontece desde o séc. XVIII e inclui um Baile de Máscaras. Ser do gênero masculino e estar mascarado são critérios para participação. Também me interessa investigar conexões de sentidos lúdicos, mágicos, estéticos e morais que observei nas diversas vezes que participei do evento. A descrição e análise que esta investigação constrói são baseadas nas múltiplas interpretações e experiências vivenciadas pelos participantes da festa. Utilizarei a perspectiva da cultura visual para compreender o uso simbólico da máscara, investigando como os participantes interpretam e problematizam práticas e valores vinculados a ela durante a festa. De orientação etnográfica, a pesquisa compreenderá análise de imagens de máscaras, entrevistas com artesãos, usuários de máscaras e participantes da festa, incluindo uma mulher da comunidade (não participante) que servirá de contraponto e olhar externo ao evento.

Palavras-chave: Máscaras, aprendizagem, cultura visual. 